\title{
44003 - ANTICATABOLIC EFFECT OF EPIDURAL ANALGESIA AND HYPOCALORIC GLUCOSE
}

\author{
Ralph Lattermann, Department of Anesthesia, Royal Victoria Hospital, McGill, Montreal, \\ QC, Canada; \\ Linda Wykes, School of Dietetics and Human Nutrition, McGill University; \\ Leopold Eberhart, Department of Anesthesia and Intensive Care, Marburg University; \\ F Carli, Department of Anesthesia, McGill University; \\ $S$ Meterissian, Department of Surgery, McGill University; \\ T Schricker, Department of Anesthesia, McGill University;
}

INTRODUCTION: Intraoperative epidural anesthesia followed by continuous epidural analgesia in contrast to general anesthesia alone combined with postoperative intravenous analgesia using morphine has been shown to prevent the loss of whole body protein on the second day after colorectal surgery. ${ }^{1}$ In this study all patients received glucose infusions at a hypocaloric rate from 24 hours before until 2 days after the operation. The goal of the present study was to investigate whether the anticatabolic effects of epidural analgesia in the presence of intravenous energy supply can be also obtained with a later, intraoperative start of glucose.

METHODS: After approval from the local Ethics Committee and after obtaining written informed consent, twenty patients undergoing colorectal surgery for cancer were randomly assigned to receive general anaesthesia combined with epidural anesthesia with bupivacaine followed by epidural analgesia using bupivacaine/fentanyl (EDA, $n=10$ ), or to receive general anesthesia alone followed by patient controlled analgesia with intravenous morphine (PCA, $\mathrm{n}=10$ ). All patients received a 48 -h infusion of glucose $10 \%$ from surgical skin incision until the second day after surgery. The glucose infusion rate provided $50 \%$ of the patients' resting energy expenditure. Protein catabolism, i.e. protein breakdown, amino acid oxidation and protein synthesis, was assessed by stable isotope tracer kinetics using primed-continuous infusions of L[1-13C]leucine before and two days after surgery. Statistical analysis was performed using ANOVA for repeated measures.

RESULTS: Protein breakdown increased in the PCA group from $112 \pm 29 \mu \mathrm{mol} / \mathrm{kg} / \mathrm{h}$ to $130 \pm 25$ $\mu \mathrm{mol} / \mathrm{kg} / \mathrm{h}$. This increase was more pronounced than in the EDA group (preoperative $120 \pm 24 \mu \mathrm{mol} / \mathrm{kg} / \mathrm{h}$, postoperative $123 \pm 22 \mu \mathrm{mol} / \mathrm{kg} / \mathrm{h}, \mathrm{p}=0.0028$ ). Amino acid oxidation postoperatively increased independent of the type of analgesia (PCA group from $17 \pm 8 \mu \mathrm{mol} / \mathrm{kg} / \mathrm{h}$ to $23 \pm 8 \mu \mathrm{mol} / \mathrm{kg} / \mathrm{h}$, EDA group from $17 \pm 6 \mu \mathrm{mol} / \mathrm{kg} / \mathrm{h}$ to $19 \pm 7 \mu \mathrm{mol} / \mathrm{kg} / \mathrm{h}, \mathrm{p}=0.067)$. Protein synthesis after surgery remained unchanged in both groups.

DISCUSSION: Epidural analgesia inhibits the increase in whole body protein breakdown in patients receiving perioperative hypocaloric glucose infusion initiated with surgical skin incision, but does not affect amino acid oxidation and protein synthesis after surgery.

REFERENCES:

1. Ann Surg 2004 240: 916-921 